\title{
Replication of somatic micronuclei in bovine enucleated oocytes
}

\author{
Natalia Canel, Romina Bevacqua, María Inés Hiriart and Daniel Salamone*
}

\begin{abstract}
Background: Microcell-mediated chromosome transfer (MMCT) was developed to introduce a low number of chromosomes into a host cell. We have designed a novel technique combining part of MMCT with somatic cell nuclear transfer, which consists of injecting a somatic micronucleus into an enucleated oocyte, and inducing its cellular machinery to replicate such micronucleus. It would allow the isolation and manipulation of a single or a low number of somatic chromosomes.

Methods: Micronuclei from adult bovine fibroblasts were produced by incubation in $0.05 \mu \mathrm{g} / \mathrm{ml}$ demecolcine for $46 \mathrm{~h}$ followed by $2 \mathrm{mg} / \mathrm{ml}$ mitomycin for $2 \mathrm{~h}$. Cells were finally treated with $10 \mu \mathrm{g} / \mathrm{ml}$ cytochalasin B for $1 \mathrm{~h}$. In vitro matured bovine oocytes were mechanically enucleated and intracytoplasmatically injected with one somatic micronucleus, which had been previously exposed [Micronucleus- injected (+)] or not [Micronucleus- injected (-)] to a transgene (50 ng/ $\mu \mathrm{l} \mathrm{pCX-EGFP)} \mathrm{during} 5 \mathrm{~min}$. Enucleated oocytes [Enucleated $(+)$ ] and parthenogenetic [Parthenogenetic (+)] controls were injected into the cytoplasm with less than $10 \mathrm{pl}$ of PVP containing $50 \mathrm{ng} / \mathrm{\mu l}$ pCX-EGFP. A non-injected parthenogenetic control [Parthenogenetic (-)] was also included. Two hours after injection, oocytes and reconstituted embryos were activated by incubation in $5 \mu \mathrm{M}$ ionomycin for $4 \mathrm{~min}+1.9 \mathrm{mM}$ 6-DMAP for $3 \mathrm{~h}$. Cleavage stage and egfp expression were evaluated. DNA replication was confirmed by DAPI staining. On day 2, Micronucleus- injected (-), Parthenogenetic (-) and in vitro fertilized (IVF) embryos were karyotyped. Differences among treatments were determined by Fisher/s exact test $(p \leq 0.05)$.

Results: All the experimental groups underwent the first cell divisions. Interestingly, a low number of Micronucleus-injected embryos showed egfp expression. DAPI staining confirmed replication of micronuclei in most of the evaluated embryos. Karyotype analysis revealed that all Micronucleus-injected embryos had fewer than 15 chromosomes per blastomere (from 1 to 13), while none of the IVF and Parthenogenetic controls showed less than 30 chromosomes per spread.
\end{abstract}

Conclusions: We have developed a new method to replicate somatic micronuclei, by using the replication machinery of the oocyte. This could be a useful tool for making chromosome transfer, which could be previously targeted for transgenesis.

Keywords: Micronuclei, Oocyte, Chromosomes, Transgene

\footnotetext{
* Correspondence: salamone@agro.uba.ar

Laboratorio Biotecnología Animal, Departamento de Producción Animal,

Facultad Agronomía, Universidad de Buenos Aires, Av. San Martín 4453,

C1417DSE, Buenos Aires, Argentina
}

\section{Biomed Central}

(c) 2012 Canel et al.; licensee BioMed Central Ltd. This is an Open Access article distributed under the terms of the Creative Commons Attribution License (http://creativecommons.org/licenses/by/2.0), which permits unrestricted use, distribution, and reproduction in any medium, provided the original work is properly cited. 


\section{Background}

Manipulation of genetic information has been under investigation for many years. However, manipulation of chromosomes has only been attempted by the generation and use of artificial chromosomes capable of carrying large DNA sequences, e.g. YAC's (yeast artificial chromosomes) [1,2] and HAC's (human artificial chromosomes [3,4]. Although such molecules can carry large fragments of DNA, the isolation and manipulation of individual entire chromosomes has never been achieved.

In 1974, Ege and Ringertz developed a methodology for generating cells with small amounts of DNA [5]. These cells, having only one or a few chromosomes (microcells) were first fused with mitotic cells to generate hybrid karyotypes by Schor et al. [6]. In 1977, Fournier and Ruddle [7] designed the microcell-mediated chromosome transfer technique (MMCT) which is still used to introduce a low number of chromosomes into host somatic cells $[8,9]$. This technique has been used in several ways, mainly for the mapping of genes, like tumor suppressor genes [10-15], telomerase suppressor genes [16-19], senescence inducing genes [20-22], and genes involved in DNA repair pathways [23-25]. It has also been used to study the effect of genomic imbalances on chromosome- specific gene expression patterns and the behavior of polysomies in different cell lines [26,27], and for analysis of genomic imprinting [28-30].

Recipient cell types used for MMCT can be somatic cells, embryonic carcinoma (EC) or embryonic stem (ES) cells, which are employed to study in vitro or in vivo effects of the transferred chromosomes [31]. This method consists of the chemical micronucleation of a donor cell line whose chromosome under study contains a dominant selectable marker. Treated cells develop several micronuclei, which contain one or, at most, a few chromosomes. Microcells are then isolated by high speed centrifugation in the presence of cytochalasin B. After a filtration process, microcells with the smallest number of chromosomes are collected and finally fused with recipient somatic cells. The dominant selectable marker previously introduced into donor cells allows recognition of resulting hybrid cell lines which have incorporated the chromosome of interest $[32,33]$. In this way, MMCT can be considered as a simple way to manipulate an entire chromosome as a structural unit. Nevertheless, it is not possible to select and replicate such chromosomes individually.

It is well known that the oocyte has the capacity to replicate varied numbers of chromosomes. It has been demonstrated that haploid, polyploid and mixoploid embryos can cleave and also reach the blastocyst stage in the bovine [34,35], porcine [36] and human [37-40]. Polyploid blastocysts have also been produced in rabbits [41] and mice [42]. Additionally, it has been established that the mammalian oocyte can replicate not only the genetic information from the gametes [43,44], but also from somatic cells $[45,46]$, including cells from different species [47]. Mouse first polar bodies have also been used as nuclear donors [48]. After injection of polar bodies, enucleated oocytes were subjected to ICSI and fertile offspring were obtained following embryo transfer to foster mothers [48]. In addition, bovine embryos reconstituted with non enucleated oocytes showed similar cleavage and blastocyst rates to those reconstituted with enucleated oocytes [49]. On the basis of these previous results, we can propose that the oocyte is capable of replicating a wide range of numbers and types of chromosomes.

The MMCT technique is still widely used, even though the methodology has not undergone any major technical changes since it was developed. In the present work, we gave a new focus to this technique by using the bovine ooplast to copy a single or low number of chromosomes. With the aim of generating several copies of individual chromosomes to be able to manipulate them, we combined part of the MMCT technique with somatic cell nuclear transfer (SCNT). The new methodology that we designed consists of injecting one somatic micronucleus into an enucleated oocyte and inducing the injected oocyte to cleave. Each blastomere from the injected oocytes should have a copy of the donor micronucleus, giving rise to the replication of an individual chromosome or of a low number of chromosomes.

We also tested the ability of somatic micronuclei to express a transgene after being injected into an ooplast. Recently, we demonstrated a spontaneous and quick interaction between DNA and donor cells or fragments of ooplasm surrounded by oolema (vesicles) [50]. In this study, cumulus cells previously exposed to pCX-EGFP plasmid for 5 min were injected into enucleated bovine oocytes and gave rise to egfp expressing embryos by SCNT. Vesicles exposed to pCX-EGFP were injected into MII oocytes and IVF embryos, resulting in the production of parthenogenetic and IVF egfp expressing embryos respectively. On the basis of these results, we hypothesize that the membranes surrounding micronuclei are also capable of binding DNA, resulting in the production of egfp expressing embryos.

In summary, after chemical activation, cleavage occurred, and some micronuclei were replicated. A low number of chromosomes (1-13) was detected. Additionally, a small proportion of micronuclei- injected oocytes showed transgene expression. The possibility of generating embryos containing only one chromosome would allow us to genetically modify, identify and transfer individual chromosomes, while multiplying them into many blastomeres. In this way, it would be possible to confirm which chromosome has been replicated by the oocyte 
through biopsy and molecular analysis of only one of the blastomeres. This method constitutes a first approach to individual chromosome manipulation.

\section{Results and discussion}

Induction of somatic micronuclei

With the aim of inducing the formation of somatic micronuclei, several chemical treatments were tested on primary cell cultures. Although there are no previous reports of the generation of micronuclei in bovine cells, we assayed different treatments to induce a block in metaphase, on the basis of human or mouse protocols $[7,10,26,51]$. Somatic cells were treated with 0.05 or $0.1 \mu \mathrm{g} / \mathrm{ml}$ demecolcine (DMC); or $0.05 \mu \mathrm{g} / \mathrm{ml}$ colchicine (Col) for 46 or $48 \mathrm{~h}$, followed or not by incubation with $2 \mathrm{mg} / \mathrm{ml}$ mitomycin (Mit) for $2 \mathrm{~h}$. The six treatments assayed were named DMC $0.05 \mu \mathrm{g} / \mathrm{ml}$; DMC $0.05 \mu \mathrm{g} / \mathrm{ml}+$ Mit; DMC $0.1 \mu \mathrm{g} / \mathrm{ml} ;$ DMC $0.1 \mu \mathrm{g} / \mathrm{ml}+$ Mit; Col $0.05 \mu \mathrm{g} / \mathrm{ml}$; and Col $0.05 \mu \mathrm{g} / \mathrm{ml}+$ Mit. A total of 300 to 500 cells per treatment were evaluated. No differences were found between groups in percentages of cells that became micronucleated over total number of cells (Table 1), except for DMC $0.05 \mu \mathrm{g} / \mathrm{ml}+$ Mit, which showed a significantly higher value ( 21.75 vs. 3.25 to $10 \%)$ $(\mathrm{p} \leq 0.05)$. All treatments induced similar numbers of micronuclei per cell, varying from 2 to 20 . Rates of micronucleation were very low compared to mouse lines from previous studies. This might be due to the cell type used as donor, because not all cells are capable of micronucleating with the same efficiency (Eric Shoubridge, personal communication). In mice, the cell line mostly used for MMCT experiments is the A9 line, which has low tumorigenicity and lacks hypoxanthine phosphoribosyltransferase and adenine phosphoribosyltransferase [52]. It has been $\mathrm{s}$ reported to have rates of micronucleation of $80-90 \%$ after a $48 \mathrm{~h}$ treatment with colcemide [7]. Because of its high efficiency, it has been widely employed for generating microcells $[8,26,53]$. On the basis of the low rates of micronucleation obtained, we decided to treat cells with mitomycin, to complete mitotic arrest, as described by
De Lonlay et al. [54] who synchronized transformed rodent cell lines. DMC $0.05 \mu \mathrm{g} / \mathrm{ml}+$ Mit treatment produced the best results, and was therefore chosen to generate micronucleate cells for further experiments.

\section{Cleavage and egfp expression of enucleated and micronucleus injected bovine oocytes}

On the basis of experiment 1, DMC $0.05 \mu \mathrm{g} / \mathrm{ml}+$ Mit treatment was employed to generate micronucleate cells. Micronuclei previously incubated or not with pCXEGFP were injected into enucleated oocytes. Cleavage rates were evaluated (Table 2). Micronucleus- injected $(+)$, Parthenogenetic $(+)$ and Parthenogenetic $(-)$ groups showed higher cleavage rates than the Micronucleusinjected $(-)$ treatment $[93 / 108$ (86.11\%), 111/136 $(81.62 \%)$ and $160 / 186(86.02 \%)$ respectively vs. $80 / 108$ $(74.07 \%)](\mathrm{p} \leq 0.05)$. Cleavage rates of the Enucleated $(+)$ group [78/105 (74.3\%)] did not differ from Micronucleus- injected (-), and Parthenogenetic $(+)$ treatments $(\mathrm{p} \leq 0.05)$. Cleavage rates were similar between groups (Table 2), except for the Micronucleus- injected (-) group, which showed a lower rate (81.62 to 86.11 vs. $64.91 \%)(\mathrm{p} \leq 0.05)$. It is important to notice that rates of cleavage are difficult to discern from those of fragmentation for the Micronucleus- injected and Enucleated groups. We considered as cleaved all embryos with more than 2 blastomeres, independent of their symmetry. This was based on the fact that embryos reconstituted with micronuclei showed both symmetric and asymmetric cells.

In experiment 2, egfp expression was also analyzed. Interestingly, a low number of Micronucleus- injected (+) embryos showed egfp expression. Expression levels were significantly lower than those observed for the Parthenogenetic $(+)$ control ( 2.15 vs. $38.74 \%$ respectively) and they did not differ from the Enucleated (+) control, which did not show egfp expression at all $(\mathrm{p} \leq 0.05)$. From these data, we can conclude that it is not necessary for the oocyte to have an entire nucleus to allow the transgene to be expressed. According to our hypothesis, the membranes surrounding micronuclei could have bound

Table 1 Evaluation of different combinations of spindle inhibitors and mitomycin for the induction of somatic micronuclei

\begin{tabular}{|c|c|c|c|}
\hline Spindle inhibitor & Mit & $\%$ Micronucleate cells / total cells & Media of micronuclei / cell \\
\hline \multirow[t]{2}{*}{ DMC $0.05 \mu \mathrm{g} / \mathrm{ml}$} & - & $10^{\mathrm{a}}$ & 7 \\
\hline & + & $25.5^{\mathrm{b}}$ & 7 \\
\hline \multirow[t]{2}{*}{ DMC $0.1 \mu \mathrm{g} / \mathrm{ml}$} & - & $6.25^{\mathrm{a}}$ & 7 \\
\hline & + & $4.25^{\mathrm{a}}$ & 8 \\
\hline \multirow[t]{2}{*}{ Col $0.05 \mu \mathrm{g} / \mathrm{ml}$} & - & $3.75^{\mathrm{a}}$ & 6 \\
\hline & + & $3.25^{\mathrm{a}}$ & 6 \\
\hline
\end{tabular}

Ovarian bovine fibroblasts were blocked in metaphase by incubation with 0.05 or $0.1 \mu \mathrm{g} / \mathrm{ml}$ DMC (Demecolcine); or $0.05 \mu \mathrm{g} / \mathrm{ml}$ Col (Colchicine) for 46 or $48 \mathrm{~h}$. In order to complete mitotic arrest, some cells were then incubated with $2 \mathrm{mg} / \mathrm{ml}$ Mit (Mitomycin) for $2 \mathrm{~h}$.

${ }^{a, b}$ : Values with different superscripts in the same column differ significantly $(p \leq 0.05)$. 
Table 2 Cleavage and egfp expression rates of Micronucleus- injected bovine oocytes

\begin{tabular}{lcccr}
\hline Treatment & pCX-EGFP & N & Cleavage (\%) & egfp expressing embryos (\%) \\
\hline Micronucleus- injected & - & 108 & $80(74.07)^{\mathrm{a}}$ & - \\
\cline { 2 - 5 } & + & 108 & $93(86.11)^{\mathrm{bc}}$ & $2(2.15)^{\mathrm{a}}$ \\
\hline Parthenogenetic & - & 186 & $160(86.02)^{\mathrm{bc}}$ & - \\
\cline { 2 - 5 } & + & 136 & $111(81.62)^{\mathrm{ac}}$ & $43(38.74)^{\mathrm{b}}$ \\
\hline Enucleated & + & 105 & $78(74.29)^{\mathrm{a}}$ & $0^{\mathrm{a}}$ \\
\hline
\end{tabular}

Micronucleus- injected (-) (embryos generated from enucleated oocytes injected with one micronucleus and parthenogenetically activated), Micronucleusinjected $(+)$ (embryos generated from enucleated oocytes injected with one micronucleus previously incubated with pCX-EGFP and parthenogenetically activated), Parthenogenetic (-) (parthenogenetically activated oocytes), Parthenogenetic $(+)$ (parthenogenetically activated oocytes injected with pCX-EGFP), Enucleated $(+)$ (enucleated oocytes injected with pCX-EGFP and parthenogenetically activated). egfp expressing embryos: embryos with 2 or more egfp expressing blastomeres (expressing embryos/cleaved embryos).

$a, b, c$ : Values with different superscripts in the same column significantly differ $(p \leq 0.05)$.

DNA, or the transgene could also have been transferred in the media during the injection of the micronuclei, as this is the way in which we produced the egfp expressing parthenogenetic control embryos. The transgene was delivered directly into the cytoplasm of the parthenotes by microinjection, before chemical activation. In a previous work done in our laboratory, eDNA alone was injected into MII oocytes in the same way and concentration of pCX-EGFP than in the present study, giving rise to a $25 \%$ of egfp expressing embryos at day 4 of in vitro development [50]. In a second study from our group, Bevacqua et al. [55] reported 50\% of egfp expressing embryos, working under the same conditions.

Although egfp expression was observed in Micronucleusinjected group, rates of expression were low. This result could indicate that a non complete nucleus is not as efficient as an entire nucleus to support transgene expression. One possible explanation for the latter observation could be the unusual structure that the micronucleus adopts at the interphase stage. There are several indirect evidences that suggest that the inner nuclear membrane might have a repressor action over transcription of many genes. One of these is that heterochromatin is usually positioned near the periphery of the nucleus [56]. In our work, we used micronuclei as nuclear donors which must have a different content of chromosomes; their transcription (and also those of the transgene) could have been repressed or not, depending on the position of the chromosomes within the nuclear envelope. On the other hand, egfp expression observed in the Enucleated (+) group was zero, while a $38.74 \%$ rate of expression shown by the Parthenogenetic $(+)$ control group is evidence that the presence of a nucleus is necessary for transgene expression. These results agree with Spann TP et al. [57] who reported an association between the normal structure of Xenopus embryo nucleus and the occurrence of transcription.

To confirm replication of DNA, some Micronucleusinjected (-) and Parthenogenetic (-) cleaved embryos were fixed and stained with DAPI (Figure 1). The presence of more than one micronucleus per embryo was evaluated. Although rates of Micronucleus- injected (-) embryos with more than 1 nucleus $(63.6 \%, n=22)$ were lower than those for the Parthenogenetic (-) group $(100 \%, \mathrm{n}=28)(\mathrm{p} \leq 0.05)$, DAPI staining confirmed replication of micronuclei. From these data, we concluded that early cleavage is not dependant on the presence of a complete nucleus. These observations could be explained by the timing of zygote genome activation. In bovine embryos, low transcription activity is observed before the 4-cell stage [58-60]. However, protein synthesis is supposed to be programmed by maternal mRNA up to the 8 -cell. It is between the 8-cell and 16-cell stage when the zygote genome becomes activated, and the higher transcription levels are detected $[61,62]$. Thus, in this context, the cytoplast could cleave without the presence of an entire nucleus. To our knowledge, this is the first report of the production of reconstituted embryos using micronuclei as nuclear donors.

\section{Chromosomal analysis of micronucleus injected embryos}

Karyotypes of Micronucleus- injected (-) embryos were studied (Table 3 and Figure 2). Parthenogenetic (-) and IVF controls were also included. All Micronucleusinjected (-) embryos analyzed had fewer than 15 chromosomes, while none of the controls showed such results. Eighteen blastomeres from 11 Micronucleus- injected (-) embryos were counted. All evaluated embryos had at least two nuclei, at metaphase or interphase. Numbers of chromosomes per blastomere varied from 1 to 13 , with a median of 7. The number of chromosomes in blastomeres from each of the eleven analyzed embryos were: $8,8,7,11$ and $11 ; 7$ and $8 ; 10+$ interphase in 4 embryos; $13+$ interphase; $6+$ interphase; $1+$ interphase; 2 and 2; 3 and 1 . Despite the efficiency of individual chromosome embryo production should be improved, these results indicate that the oocyte is capable of replicating a low number of chromosomes. It is important to note that the number of chromosomes injected into the enucleated oocytes might have been different from those we were able to count after cell divisions, as a result of chemical 

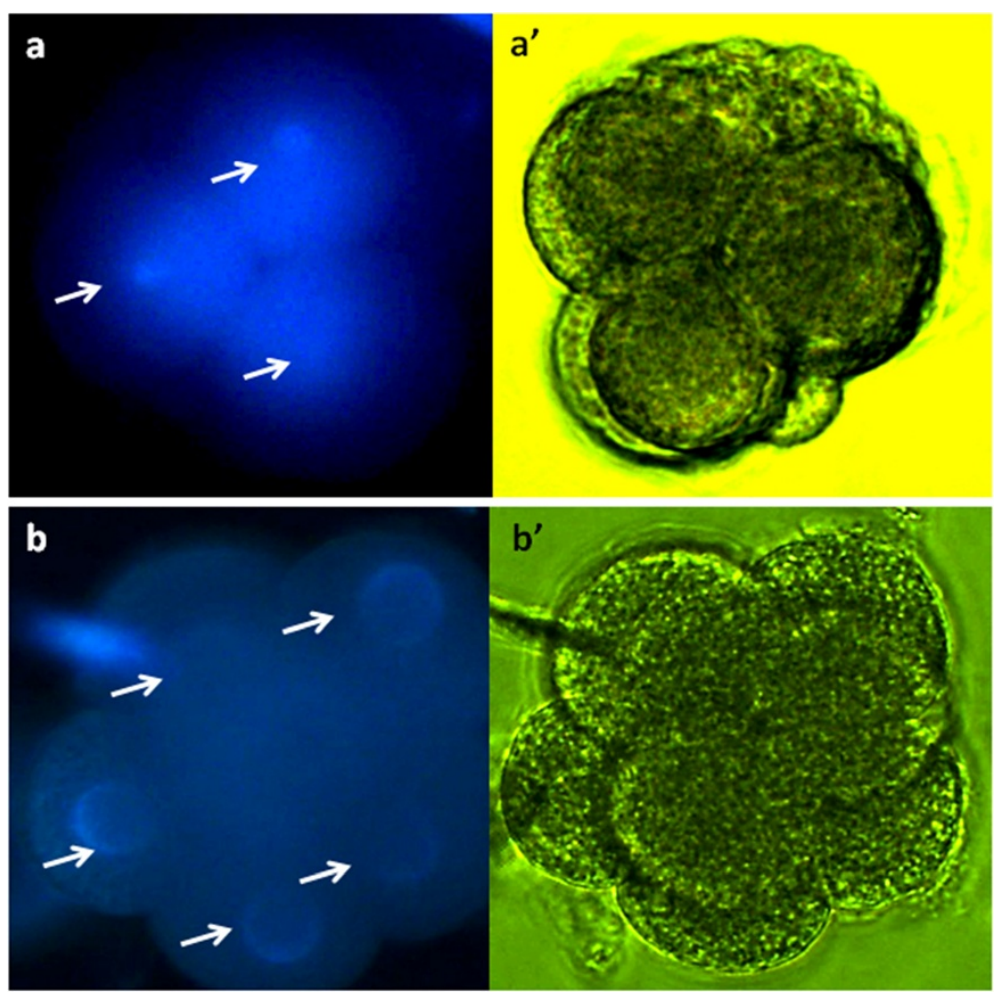

Figure 1 Assessment of nuclear replication. (a) Micronucleus- injected and (b) Parthenogenetic cleaved embryo observed under UV light after DAPI staining. (a' and $\mathbf{b}^{\prime}$ ): The same embryos under bright light. Arrows indicate DNA staining (200X).

activation. It has been previously reported that parthenogenetic $[34,35,63]$ and SCNT bovine embryos $[64,65]$ show a high incidence of abnormal karyotypes, after DMAP activation. Some authors have attributed these anomalies to the accelerated pronuclear formation and premature DNA synthesis observed in DMAP-activated oocytes, followed by karyokinesis without cytokinesis during the first cell cycle [35]. Such observations correlate with our results, which showed $55 \%$ of anomalies, while IVF controls only showed $15 \%$. In the future, this new technique could be modified to allow the replication of blastomeres containing a unique chromosome, leading to a simple way of individual chromosome transfer which could have a wide range of applications.

\section{Conclusions}

In this study we have demonstrated that bovine ooplasts are capable of replicating micronuclei with a low number of chromosomes. The number of replicated chromosomes in each micronucleus was confirmed to be between 1 and 13. Moreover, it was observed that some of the transferred micronuclei expressed a foreign DNA, which means that it is not necessary for the oocyte to have an entire nucleus to allow the expression of a transgene. For the first time, MMCT was used to produce SCNT embryos, using micronuclei as nuclear donors. In conclusion, we have developed a new method to clone a small number of chromosomes, which could be a useful tool to transfer individual chromosomes and to target transgenesis to a specific area of the genome.

Table 3 Ploidy of micronucleus injected bovine embryos

\begin{tabular}{llcccc}
\hline Treatment & $\mathbf{N}$ & Spreads & \multicolumn{2}{c}{ Embryos } \\
\cline { 4 - 7 } & & & Less than $\mathbf{1 5}$ chromosomes (\%) & Euploid (\%) & Others (\%) \\
\hline Micronucleus- injected & 11 & 18 & $11(100)^{\mathrm{a}}$ & $0^{\mathrm{a}}$ & $9(45)^{\mathrm{b}}$ \\
\hline Parthenogenetic & 20 & 52 & $0^{\mathrm{b}}$ & $11(55)^{\mathrm{b}}$ \\
\hline IVF & 20 & 49 & $0^{\mathrm{b}}$ & $3(75)^{\mathrm{b}}$
\end{tabular}

Micronucleus- injected (embryos generated from enucleated oocytes injected with one micronucleus and parthenogenetically activated), Parthenogenetic (parthenogenetically activated oocytes), IVF (embryos generated by in vitro fertilization). \%: percentages over total embryos. Euploid: haploid + diploid. Others: tetraploid + mixoploid + aneuploid.

${ }^{a, b}:$ Values with different superscripts in the same column significantly differ $(p \leq 0.05)$. 


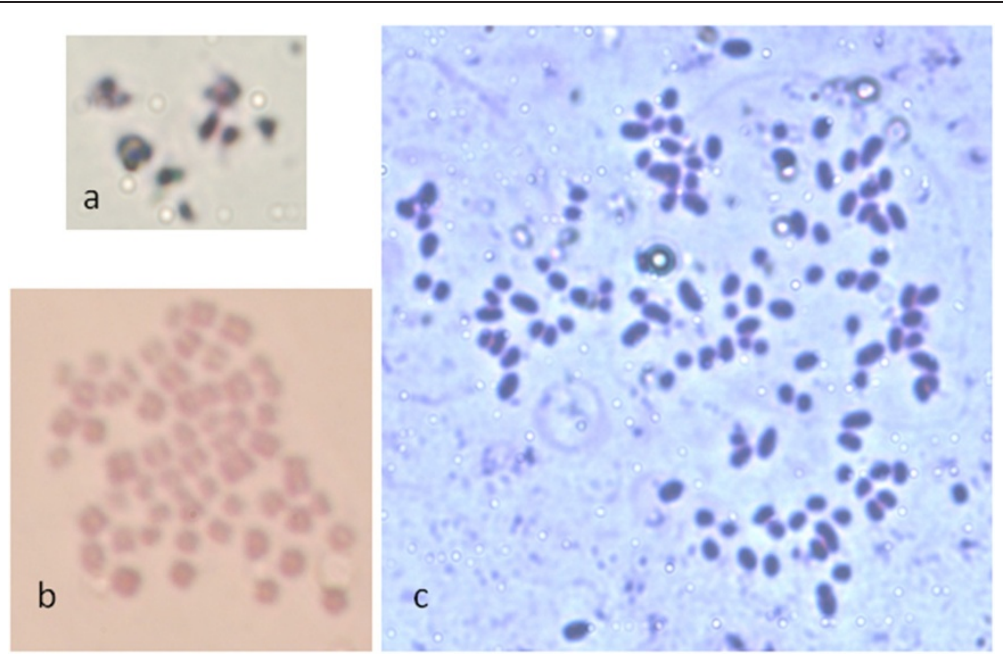

Figure 2 Chromosomal analysis. Spreads from (a) Micronucleus- injected (less than 1n), (b) IVF (2n) and (c) Parthenogenetic cleaved embryo (4n) treated with colchicine and stained with Giemsa (1000X).

In the field of domestic animals production, it could be a strategy for sex chromosomes interchange. It would make it possible to exchange an $\mathrm{X}$ chromosome for a $\mathrm{Y}$ chromosome, which could have been previously modified to carry a transgene of interest. In this way, the resulting male would be able to produce millions of gametes instead of hundreds and would have the transgene integrated into the $\mathrm{Y}$ chromosome, which has a few genes and therefore reduced position effects.

\section{Methods}

Unless otherwise indicated, all chemicals were purchased from Sigma Chemical Company (St. Louis, MO, USA).

\section{Cumulus-oocyte complexes (COCs) collection and in vitro maturation (IVM)}

Cow ovaries were transported from a local slaughterhouse to the laboratory in a thermo container at 24 to $27^{\circ} \mathrm{C}$. Cumulus oocyte complexes (COCs) were aspirated from follicles with a diameter of 2-8 mm into Dulbecco's phosphate-buffered saline (DPBS; 14287-072; Gibco BRL, Grand Island, NY, USA) containing 10\% v/v fetal bovine serum (FBS; 10499-044; Gibco BRL) and 1\% v/v antibiotic-antimycotic (ATB; 15240-096; Gibco BRL). Oocytes covered with at least three layers of granulosa cells were selected for IVM. The maturation medium was bicarbonate-buffered TCM-199 (31100-035; Gibco BRL), containing $2 \mathrm{mM}$ glutamine (G-8540), 10\% v/v FBS, $2 \mathrm{mg} / \mathrm{ml}$ follicle-stimulating hormone (NIH-FSH-P1; Folltropin; Bioniche, Belleville, Ontario, Canada), $0.3 \mathrm{mM}$ sodium pyruvate (P2256), $100 \mathrm{mM}$ cysteamine (M9768), and $1 \% \mathrm{v} / \mathrm{v}$ ATB. Groups of $25 \mathrm{COCs}$ were in vitro matured in $100 \mu \mathrm{L}$ droplets of maturation medium covered with mineral oil (M8410), at $39^{\circ} \mathrm{C}$ in a humidified atmosphere of
6\% $\mathrm{CO}_{2}$ in air. After $21-24 \mathrm{~h}$ of IVM, cumulus cells were removed from COCs by vortexing for $3 \mathrm{~min}$ in $1 \mathrm{mg} / \mathrm{ml}$ hyaluronidase solution (H-4272) and washed three times in HEPES-TALP. Oocytes with an extruded first polar body $(\mathrm{PB})$ were selected for enucleation and intracytoplasmic micronucleus injection or chemical activation.

\section{Preparation of donor cells}

Somatic cell cultures were established from slaughtered cow ovaries. Ovarian explants were cultured in $35 \times 100$ mm culture dishes (353001; Falcon, USA) with Dulbecco modified Eagle medium (DMEM; 11885 Low glucose; Invitrogen, Grand Island, NY, USA) supplemented with $10 \% \mathrm{v} / \mathrm{v} \mathrm{FBS}$ and $3 \% \mathrm{v} / \mathrm{v} \mathrm{ATB}$, at $39^{\circ} \mathrm{C}$ in a humidified atmosphere of $6 \% \mathrm{CO}_{2}$ in air. After about 2 weeks, fibroblast monolayers reached confluence and were removed and placed into new culture dishes. For passages, cells were washed with DPBS and digested with 0.05\% trypsin-EDTA (25300; Gibco, Grand Island, NY) for 5 min at $37^{\circ} \mathrm{C}$. The reaction was terminated by adding supplemented DMEM and the collected cells were resuspended and divided into new dishes.

\section{Induction of somatic micronucleate cells}

Ovarian bovine fibroblasts at approximately $80 \%$ confluence with less than 5 passages were blocked in metaphase by incubation with 0.05 or $0.1 \mu \mathrm{g} / \mathrm{ml}$ demecolcine (DMC; D1925); or $0.05 \mu \mathrm{g} / \mathrm{ml}$ colchicine (Col; C3915) in DMEM for 46 or $48 \mathrm{~h}$. In order to complete mitotic arrest, some cells were then incubated with $2 \mathrm{mg} / \mathrm{ml}$ mitomycin (Mit; M-4287) for $2 \mathrm{~h}$. The cells were subsequently washed with DPBS and, in all cases, were incubated in DMEM medium supplemented with 10 to $15 \mu \mathrm{g} / \mathrm{ml}$ 
cytochalasin B (CB; C6762) for $1 \mathrm{~h}$. The six treatments assayed were: DMC $0.05 \mu \mathrm{g} / \mathrm{ml}$; DMC $0.05 \mu \mathrm{g} / \mathrm{ml}+$ Mit; DMC $0.1 \mu \mathrm{g} / \mathrm{ml}$; DMC $0.1 \mu \mathrm{g} / \mathrm{ml}+$ Mit; Col $0.05 \mu \mathrm{g} / \mathrm{ml}$; and $\mathrm{Col} 0.05 \mu \mathrm{g} / \mathrm{ml}+$ Mit. All treated cells were trypsinized and immediately centrifuged at 1200 r.p.m for 5 $\mathrm{min}$, at $37^{\circ} \mathrm{C}$. The pellet was resuspended in $200 \mu \mathrm{l}$ of FBS-free DMEM medium and the resulting suspension containing micronucleate cells was transferred to $100 \mu \mathrm{l}$ droplets of TALP-Hepes with $1 \mathrm{mg} / \mathrm{ml}$ of Hoechst Bisbenzimide 33342 (H33342, B-2261). After $10 \mathrm{~min}$, cells were observed under a fluorescence microscope to analyze the percentage of micronucleate cells and the number of micronuclei per cell. For injection procedures, cells were exposed to DMC $0.05 \mu \mathrm{g} / \mathrm{ml}+$ Mit + CB $10 \mu \mathrm{g} / \mathrm{ml}$ treatment, then trypsinized and immediately used as nuclear donors as described below.

\section{DNA construction}

The plasmid used was pCX-EGFP kindly provided by Dr. Masaru Okabe (Osaka University, Osaka, Japan) that contains the enhanced green fluorescent protein gene (egfp) under the chimeric cytomegalovirus-IE-chicken $\beta$-actin enhancer-promoter control [66]. The plasmid was linearized by Hind III digestion.

\section{Enucleation and intracytoplasmic micronucleus injection}

After $21 \mathrm{~h}$ of IVM, MII oocytes were denuded and stained with $1 \mathrm{mg} / \mathrm{ml}$ of $\mathrm{H} 33342$ for $10 \mathrm{~min}$. Immediately, oocytes were transferred into $100 \mu \mathrm{l}$ droplets of Hepes-TALP supplemented with $0.3 \mathrm{~g} / \mathrm{ml}$ BSA, under mineral oil, in 100x20 mm tissue culture dishes (430167; Corning, NY, USA) and mechanically enucleated using a Narishige hydraulic micromanipulator (Narishige Sci., Tokyo, Japan) mounted on a Nikon Eclipse E-300 microscope (Nikon, Melville, NY, USA). Enucleation was performed using a $20 \mu \mathrm{m}$ internal diameter pipette. Metaphase chromosomes were visualized under ultraviolet light $(<10 \mathrm{sec})$ and aspirated into the pipette with a minimal volume of ooplasm. Chromosome removal was confirmed by the presence of stained MII chromosomes inside the pipette. Donor somatic cells were transferred to TALP-Hepes droplets supplemented with $10 \mu \mathrm{g} / \mathrm{ml} \mathrm{CB}$ and $1 \mathrm{mg} / \mathrm{ml}$ of $\mathrm{H} 33342$. After $10 \mathrm{~min}$, micronucleate cells were identified and transferred to $3 \mu \mathrm{l}$ droplets of $10 \% \mathrm{v} / \mathrm{v}$ polyvinylpyrrolidone solution (PVP; 99219; Irvine Sci., Irvine, CA, USA) in HEPES-TALP, with or without $50 \mathrm{ng} / \mu \mathrm{l} \mathrm{pCX-EGFP} \mathrm{for} \mathrm{injection.} \mathrm{After} \mathrm{an} \mathrm{incubation} \mathrm{of}$ at least $5 \mathrm{~min}$, the cell membrane was broken by gentle aspiration in and out of the injection pipette (inner diameter of $7 \mu \mathrm{m}$ ) and a single micronucleus was injected into the cytoplasm of each enucleated oocyte (Micronucleusinjected groups). Aspiration was used to break the oolemma. The somatic micronucleus and the aspirated ooplasm were then expelled into the oocyte with a minimal volume of PVP $(<10 \mathrm{pl})$. Enucleated and some parthenogenetic controls were injected with $50 \mathrm{ng} / \mu \mathrm{l}$ pCX-EGFP in 10\% v/v PVP into the ooplasm, using a volume that was equivalent to that used for to the injection of micronuclei $(<10 \mathrm{pl})$. A parthenogenetic control (non injected) was also included. After injection, all groups were subjected to chemical activation as described below.

\section{Chemical activation}

Metaphase II oocytes and Micronucleus- injected embryos were treated with $5 \mu \mathrm{M}$ ionomycin (I24222; Invitrogen, Carlsbad, CA, USA) in HEPES-TALP for 4 min, followed by incubation for $3 \mathrm{~h}$ in $1.9 \mathrm{mM}$ 6-DMAP, (D2629) diluted in TCM-199 medium. Afterwards, oocytes were thoroughly washed in HEPES-TALP and cultured as described below. Prior to activation, Micronucleus- injected embryos were held for $2 \mathrm{~h}$ in $100 \mu \mathrm{l}$ droplets of TCM-199 to allow the reprogramming events.

\section{IVF procedure}

The IVF procedure was previously described by Brackett and Oliphant [67]. Briefly, frozen semen was thawed in a $37^{\circ} \mathrm{C}$ water bath for $30 \mathrm{sec}$. The sperm were washed twice by centrifugation at $490 \mathrm{~g}$ x 5 min with Brackett's defined medium. Sperm concentration was adjusted to $20 \times 10^{6} / \mathrm{ml}$ and sperm were then coincubated for $5 \mathrm{~h}$ with COCs in Brackett's fertilization medium. Afterward, presumptive zygotes were washed several times in HEPES-TALP and in vitro cultured as described below.

\section{In vitro culture}

Embryos were in vitro cultured in $50 \mu \mathrm{l}$ droplets of synthetic oviductal fluid (SOF) [68] modified by Holm et al. [69] containing $2.5 \% \mathrm{v} / \mathrm{v}$ FBS under mineral oil, at $39^{\circ} \mathrm{C}$ in a humidified atmosphere of $6 \% \mathrm{CO}_{2}$ in air. Cleavage stage was evaluated at day 2 of in vitro development.

\section{Evaluation of pCX-EGFP expression in embryos}

Embryos injected with pCX-EGFP were briefly exposed to blue light using an excitation- filter at $488 \mathrm{~nm}$ and an emission-filter at $530 \mathrm{~nm}$ to determine egfp expression at day 4 of in vitro development.

\section{Assessment of nuclear replication}

Forty-eight hours after activation, Micronucleus- injected and Parthenogenetic embryos were transferred to HepesTALP droplets and treated with $1.5 \mathrm{mg} / \mathrm{ml}$ pronase for 3 min to remove all zonae pellucidae. Afterward, embryos were fixed with methanol: acetic acid solution (3:1, v: v) and DNA was stained with DAPI (D9542). Nuclei were visualized and counted using UV light under a fluorescence microscope. Embryos with more than one nucleus were considered to have replicated their DNA. 


\section{Chromosomal analysis}

Forty-eight hours after activation, Micronucleus- injected, Parthenogenetic, and IVF embryos were cultured for $6 \mathrm{~h}$ in SOF medium containing $1.25 \mu \mathrm{g} / \mathrm{ml}$ colchicine (C3915) and transferred to a trisodium citrate hypotonic solution (F71497; $0.9 \% \mathrm{w} / \mathrm{v}$ in distilled water) for $13 \mathrm{~min}$ at $37^{\circ} \mathrm{C}$. Subsequently, embryos were placed on a clean glass slide in a small volume of medium and a methanol: acetic acid solution (3:1, v: v) was applied. After air drying, fixed embryos were stained with $5 \% \mathrm{v} / \mathrm{v}$ Giemsa solution (1.09204.1002; Merck, Darmstadt, Germany) in distilled water for $10 \mathrm{~min}$. Chromosome spreads were examined under a 100X oil magnification objective and chromosomal complements were determined for each embryo which was classified as: less than 15 chromosomes, euploid (1n and 2n), and others, which included tetraploid (4n), mixoploid (embryos with blastomeres of different ploidies), and aneuploid. Only those spreads which were clearly in metaphase were analyzed.

\section{Statistical analysis}

Each experiment was repeated at least three times. Differences between treatments in each experiment were determined by Fisher's exact test using Graph Pad PRISM $^{\circledR}$ software 5.01 version. Differences between media of micronuclei per cell were analyzed for significance using the one way ANOVA. For all analyses a difference of $\mathrm{p} \leq 0.05$ was considered to be significant.

\section{Experimental design}

In experiment 1 , six different treatments were assayed on primary fibroblast cultures to induce micronucleus formation. In experiment 2, the best treatment from experiment 1 was employed to generate micronuclei, which were used as nuclear donors of reconstituted embryos. The methodology is shown in Figure 3. Briefly, micronucleus formation was induced by incubation in $0.05 \mu \mathrm{g} / \mathrm{ml}$ demecolcine for $46 \mathrm{~h}$ followed by $2 \mathrm{mg} / \mathrm{ml}$ mitomycin for $2 \mathrm{~h}$. Cells were then treated with $10 \mu \mathrm{g} / \mathrm{ml}$ cytochalasin B for $1 \mathrm{~h}$. Metaphase II oocytes were mechanically enucleated and injected with one somatic micronucleus, which had been previously exposed or not to pCX-EGFP. Enucleated oocytes and parthenogenetic controls were injected with $50 \mathrm{ng} / \mu \mathrm{l} \mathrm{pCX}$-EGFP. A non injected parthenogenetic control was also included. After 2 $h$, oocytes and reconstituted embryos were chemically activated. Cleavage stage and egfp expression were evaluated. Additionally, DNA replication from some Micronucleusinjected and Parthenogenetic embryos was confirmed by DAPI staining. In experiment 3, Micronucleus- injected, Parthenogenetic and in vitro fertilized (IVF) embryos were karyotyped. Methodological design is summarized in Figure 3.

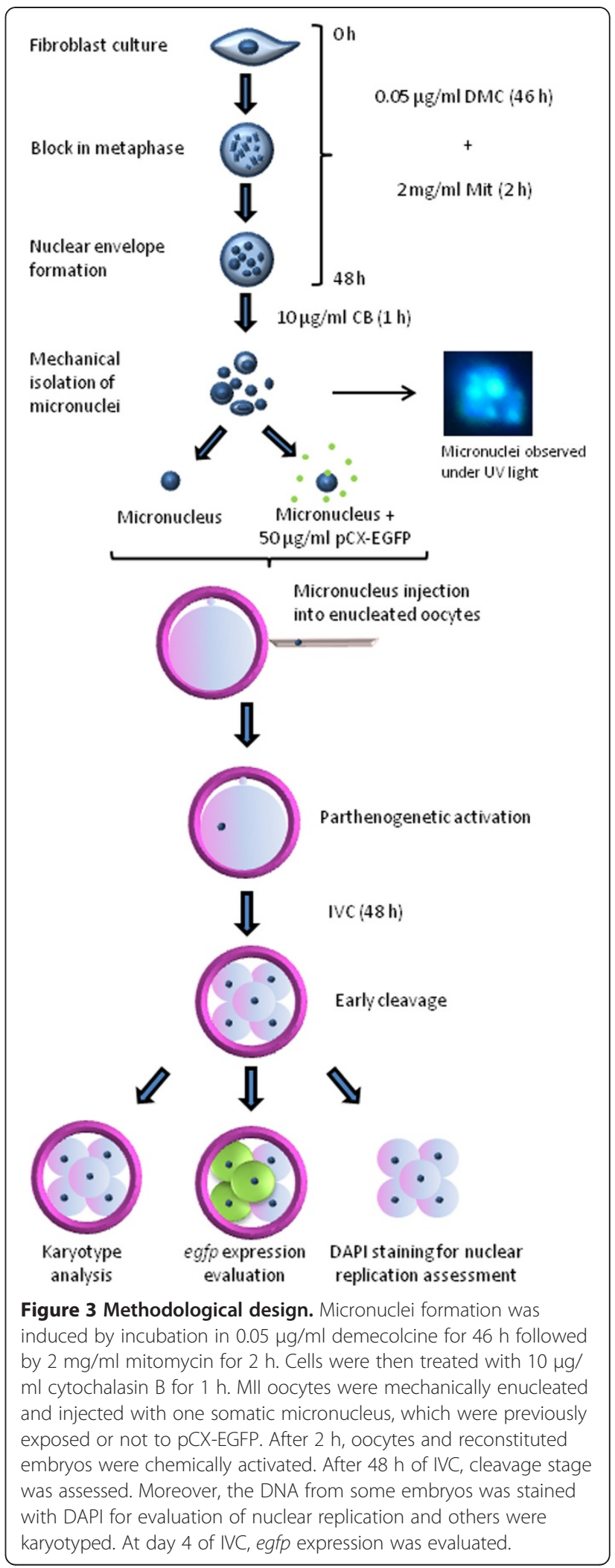




\section{Competing interests}

The authors declare that they have no competing interests.

\section{Authors' contributions}

DS and NC designed the experiments and NC, RB and MIH performed all the experiments. NC, RB and DS performed the data analysis. NC wrote the manuscript and DS is responsible for the scientific content of the manuscript. All authors have read and approved the final manuscript.

\section{Acknowledgements}

The authors are grateful to Dr. Masaru Okabe for kindly providing the construct pCX-EGFP and C.I.A.L.E. for providing bull semen. The authors would also like to thank Dr. Elizabeth Crichton (bethiberg@aol.com) for her assistance to improve the English and Dr. Rafael Fernández y Martín, Lic. Pablo Zipowicz and Dr. Martín Radrizani for their technical support. The research was supported by funds from the Agencia Nacional de Promoción Científica y Tecnológica (PICT Bicentenario №10-2716).

Received: 6 August 2012 Accepted: 15 November 2012

Published: 22 November 2012

\section{References}

1. Murray AW, Szostak JW: Construction of artificial chromosomes in yeast. Nature 1983, 305:189-193.

2. Burke DT, Carle GF, Olson MV: Cloning of large segments of exogenous DNA into yeast by means of artificial chromosome vectors. Science 1987, 236:806-812.

3. Harrington JJ, Van BG, Mays RW, Gustashaw K, Willard HF: Formation of de novo centromeres and construction of first-generation human artificial microchromosomes. Nature Genet 1997, 15:345-355.

4. Kuroiwa Y, Tomizuka K, Shinohara T, Kazuki Y, Yoshida H, Ohguma A, Yamamoto T, Tanaka S, Oshimura M, Ishida I: Manipulation of human minichromosomes to carry greater than megabase-sized chromosome inserts. Nat Biotechnol 2000, 18:1086-1090.

5. Ege T, Ringertz NR: Preparation of microcells by enucleation of micronucleate cells. Exp Cell Res 1974, 87:378-382.

6. Schor SL, Johnson RT, Mullinger AM: Perturbation of mammalian cell division. II. Studies on the isolation and characterization of human mini segregant cells. J Cell Sci 1975, 19:281-303.

7. Fournier RE, Ruddle FH: Microcell-mediated transfer of murine chromosomes into mouse, Chinese hamster, and human somatic cells. Proc Natl Acad Sci USA 1977, 74:319-23.

8. Suzuki N, Itou T, Hasegawa Y, Okazaki T, Ikeno M: Cell to cell transfer of the chromatin-packaged human beta-globin gene cluster. Nucleic Acids Res 2010, 38:e33.

9. Kazuki Y, Hiratsuka M, Takiguchi M, Osaki M, Kajitani N, Hoshiya H, Hiramatsu K, Yoshino T, Kazuki K, Ishihara C, Takehara S, Higaki K, Nakagawa M, Takahashi K, Yamanaka S, Oshimura M: Complete genetic correction of ips cells from Duchenne muscular dystrophy. Mol Ther 2010, 18:386-93.

10. Saxon PJ, Srivatsan ES, Stanbridge EJ: Introduction of human chromosome 11 via microcell transfer controls tumorigenic expression of HeLa cells. EMBO J 1986, 5:3461-6.

11. Casey G, Plummer S, Hoeltge G, Scanlon D, Fasching C, Stanbridge EJ: Functional evidence for a breast cancer growth suppressor gene on chromosome 17. Hum Mol Genet 1993, 2:1921-7.

12. Flanagan JM, Healey S, Young J, Whitehall V, Trott DA, Newbold RF, Chenevix-Trench G: Mapping of a candidate colorectal cancer tumorsuppressor gene to a 900-kilobase region on the short arm of chromosome 8. Genes Chromosomes Cancer 2004, 40:247-60.

13. Cheung AK, Lung HL, Ko JM, Cheng Y, Stanbridge EJ, Zabarovsky ER, Nicholls JM, Chua D, Tsao SW, Guan XY, Lung ML: Chromosome 14 transfer and functional studies identify a candidate tumor suppressor gene, mirror image polydactyly 1, in nasopharyngeal carcinoma. Proc Natl Acad Sci USA 2009, 106:14478-83.

14. Dafou D, Grun B, Sinclair J, Lawrenson K, Benjamin EC, Hogdall E, KrugerKjaer S, Christensen L, Sowter HM, Al-Attar A, Edmondson R, Darby S, Berchuck A, Laird PW, Pearce CL, Ramus SJ, Jacobs IJ, Gayther SA: Microcellmediated chromosome transfer identifies EPB41L3 as a functional suppressor of epithelial ovarian cancers. Neoplasia 2010, 12:579-89.

15. Notaridou M, Quaye L, Dafou D, Jones C, Song H, Høgdall E, Kjaer SK, Christensen L, Høgdall C, Blaakaer J, McGuire V, Wu AH, Van Den Berg DJ,
Pike MC, Gentry-Maharaj A, Wozniak E, Sher T, Jacobs IJ, Tyrer J, Schildkraut JM, Moorman PG, Iversen ES, Jakubowska A, Mędrek K, Lubiński J, Ness RB, Moysich KB, Lurie G, Wilkens LR, Carney ME, et al: Common alleles in candidate susceptibility genes associated with risk and development of epithelial ovarian cancer. Int J Cancer 2011, 128:2063-74.

16. Nakabayashi K, Ogino H, Michishita E, Satoh N, Ayusawa D: Introduction of chromosome 7 suppresses telomerase with shortening of telomeres in a human mesothelial cell line. Exp Cell Res 1999, 252:376-82.

17. Backsch C, Wagenbach N, Nonn M, Leistritz S, Stanbridge E, Schneider A, Dürst M: Microcell-mediated transfer of chromosome 4 into HeLa cells suppresses telomerase activity. Genes Chromosomes Cancer 2001, 31:196-8.

18. Abe S, Tanaka H, Notsu T, Horike S, Fujisaki C, Qi DL, Ohhira T, Gilley D, Oshimura $\mathrm{M}$, Kugoh $\mathrm{H}$ : Localization of an hTERT repressor region on human chromosome 3p21.3 using chromosome engineering. Genome Integr 2010, 26:6.

19. Qi DL, Ohhira T, Fujisaki C, Inoue T, Ohta T, Osaki M, Ohshiro E, Seko T, Aoki S, Oshimura M, Kugoh H: Identification of PITX1 as a TERT suppressor gene located on human chromosome 5. Mol Cell Biol 2011, 31:1624-36.

20. Klein CB, Conway K, Wang XW, Bhamra RK, Lin XH, Cohen MD, Annab L, Barrett JC, Costa M: Senescence of nickel-transformed cells by an $X$ chromosome: possible epigenetic control. Science 1991, 251:796-9.

21. Kugoh H, Fujiwara M, Kihara K, Fukui I, Horikawa I, Schulz TC, Oshimura M: Cellular senescence of a human bladder carcinoma cell line (JTC-32) induced by a normal chromosome 11. Cancer Genet Cytogenet 2000, 116:158-63.

22. Poignée M, Backsch C, Beer K, Jansen L, Wagenbach N, Stanbridge EJ, Kirchmayr R, Schneider A, Dürst M: Evidence for a putative senescence gene locus within the chromosomal region 10p14-p15. Cancer Res 2001, 61:7118-21.

23. Jeggo PA, Hafezparast M, Thompson AF, Broughton BC, Kaur GP, Zdzienicka MZ, Athwal RS: Localization of a DNA repair gene (XRCC5) involved in double-strand-break rejoining to human chromosome 2. Proc Natl Acad Sci USA 1992, 89:6423-7.

24. Chen DJ, Marrone BL, Nguyen T, Stackhouse M, Zhao Y, Siciliano MJ: Regional assignment of a human DNA repair gene (XRCC5) to 2q35 by X-ray hybrid mapping. Genomics 1994, 21:423-7.

25. Whitney M, Thayer M, Reifsteck C, Olson S, Smith L, Jakobs PM, Leach R, Naylor S, Joenje H, Grompe M: Microcell mediated chromosome transfer maps the Fanconi anaemia group D gene to chromosome 3p. Nat Genet 1995, 11:341-3.

26. Upender MB, Habermann JK, MCShane LM, Korn EL, Barrett JC, Difilippantonio MJ, Ried T: Chromosome transfer induced aneuploidy results in complex dysregulation of the cellular transcriptome in immortalized and cancer cells. Cancer Res 2004, 64:6941-9.

27. Nawata H, Kashino G, Tano K, Daino K, Shimada Y, Kugoh H, Oshimura M, Watanabe M: Dysregulation of gene expression in the artificial human trisomy cells of chromosome 8 associated with transformed cell phenotypes. PloS One 2011, 6:e25319.

28. Meguro M, Mitsuya K, Sui H, Shigenami K, Kugoh H, Nakao M, Oshimura M: Evidence for uniparental, paternal expression of the human GABAA receptor subunit genes, using microcell-mediated chromosome transfer. Hum Mol Genet 1997, 6:2127-33.

29. Kugoh H, Mitsuya K, Meguro M, Shigenami K, Schulz TC, Oshimura M: Mouse A9 cells containing single human chromosomes for analysis of genomic imprinting. DNA Res 1999, 6:165-72.

30. Inoue J, Mitsuya K, Maegawa S, Kugoh H, Kadota M, Okamura D, Shinohara T, Nishihara S, Takehara S, Yamauchi K, Schulz TC, Oshimura M: Construction of 700 human/mouse $\mathrm{A} 9$ monochromosomal hybrids and analysis of imprinted genes on human chromosome 6. J Hum Genet 2001, 46:137-45.

31. Doherty AM, Fisher EM: Microcell-mediated chromosome transfer (MMCT): small cells with huge potential. Mamm Genome 2003, 14:583-92.

32. Anderson MJ, Stanbridge EJ: Tumor suppressor genes studied by cell hybridization and chromosome transfer. FASEB J 1993, 7:826-833.

33. Meaburn KJ, Parris CN, Bridger JM: The manipulation of chromosomes by mankind: the uses of microcell-mediated chromosome transfer. Chromosoma 2005, 114:263-74.

34. Winger QA, De La Fuente R, King WA, Armstrong DT, Watson AJ: Bovine parthenogenesis is characterized by abnormal chromosomal complements: implications for maternal and paternal co-dependence during early bovine development. Dev Genet 1997, 21:160-6. 
35. De La Fuente R, King WA: Developmental consequences of karyokinesis without cytokinesis during the first mitotic cell cycle of bovine parthenotes. Biol Reprod 1998, 58:952-62.

36. Hao YH, Lai LX, Liu ZH, Im GS, Wax D, Samuel M, Murphy CN, Sutovsky P, Prather RS: Developmental competence of porcine parthenogenetic embryos relative to embryonic chromosomal abnormalities. Mol Reprod Dev 2006, 73:77-82.

37. Angell RR, Templeton AA, Aitken RJ: Chromosome studies in human in vitro fertilization. Hum Genet 1986, 72:333-9.

38. Munné S, Lee A, Rosenwaks Z, Grifo J, Cohen J: Diagnosis of major chromosome aneuploidies in human preimplantation embryos. Hum Reprod 1993, 8:2185-91.

39. Pellestor F, Girardet A, Andréo B, Arnal F, Humeau C: Relationship between morphology and chromosomal constitution in human preimplantation embryo. Mol Reprod Dev 1994, 39:141-6.

40. Clouston HJ, Herbert M, Fenwick J, Murdoch AP, Wolstenholme J: Cytogenetic analysis of human blastocysts. Prenat Diagn 2002, 22:1143-52.

41. Shaver EL, Carr DH: Chromosome abnormalities in rabbit blastocysts following delayed fertilization. J Reprod Fertil 1967, 14:415-20.

42. Modlinski JA: Transfer of embryonic nuclei to fertilized mouse eggs and development of tetraploid blastocysts. Nature 1978, 273:466-7.

43. Vichera G, Olivera R, Sipowicz P, Radrizzani M, Salamone D: Sperm genome cloning used in biparental bovine embryo reconstruction. Reprod Fertil Dev 2011, 23:769-79.

44. Vichera G, Olivera R, Salamone D: Oocyte genome cloning used in biparental bovine embryo reconstruction. Zygote 2012, 5:1-9.

45. McGrath J, Solter D: Nuclear transplantation in mouse embryo by microsurgery and cell fusion. Science 1983, 220:1300-1302

46. Wilmut I, Schnieke AE, McWhir J, Kind AJ, Campbell KH: Viable offspring derived from fetal and adult mammalian cells. Nature 1997, 385:810-813.

47. Dominko T, Mitalipova M, Haley B, Beyhan Z, Memili E, McKusick B, First NL: Bovine oocyte cytoplasm supports development of embryos produced by nuclear transfer of somatic cell nuclei from various mammalian species. Biol Reprod 1999, 60:1496-1502.

48. Wakayama T, Yanagimachi R: The first polar body can be used for the production of normal offspring in mice. Biol Reprod 1998, 59:100-4.

49. Meng Q, Bai C, Liu Y, Wu X, Bunch TD, Li GP: In vitro development and chromosomal configuration of bovine somatic cloned embryos with nonenucleated metaphase II oocytes. Cell Reprogram 2010, 12:481-90.

50. Pereyra-Bonnet F, Bevacqua R, La Rosa I, Sipowicz P, Radrizzani M, Fernandez-Martin R, Salamone D: Novel methods to induce exogenous gene expression in SCNT, parthenogenic and IVF preimplantation bovine embryos. Transgenic Res 2011, 20:1379-88.

51. Katoh M, Kazuki Y, Kazuki K, Kajitani N, Takiguchi M, Nakayama Y, Nakamura T, Oshimura M: Exploitation of the interaction of measles virus fusogenic envelope proteins with the surface receptor CD46 on human cells for microcell-mediated chromosome transfer. BMC Biotechnol 2010, 10:37.

52. Littlefield JW: The use of drug-resistant markers to study the hybridization of mouse fibroblasts. Exp Cell Res 1966, 41:190-196.

53. Horibata K, Iwamoto Y, Kuraoka I, Jaspers NG, Kurimasa A, Oshimura M, Ichihashi M, Tanaka K: Complete absence of Cockayne syndrome group B gene product gives rise to UV-sensitive syndrome but not Cockayne syndrome. Proc Natl Acad Sci USA 2004, 101:15410-5.

54. De Lonlay P, Mugnier C, Sanlaville D, Chantrel-Groussard K, Bénit P, Lebon S, Chrétien D, Kadhom N, Saker S, Gyapay G, Romana S, Weissenbach J, Munnich A, Rustin P, Rötig A: Cell complementation using Genebridge 4 human: rodent hybrids for physical mapping of novel mitochondrial respiratory chain deficiency genes. Hum Mol Genet 2002, 11:3273-81.

55. Bevacqua RJ, Pereyra-Bonnet F, Olivera R, Hiriart MI, Sipowicz P, FernandezMartín R, Radrizzani M, Salamone DF: Production of IVF transgeneexpressing bovine embryos using a novel strategy based on cell cycle inhibitors. Theriogenology 2012, 78:57-68.

56. Boyle S, Gilchrist S, Bridger J, Mahy N, Ellis J, Bickmore W: The spatial organization of human chromosomes within the nuclei of normal and emerin-mutant cells. Hum Mol Genet 2001, 10:211-219.

57. Spann TP, Goldman AE, Wang C, Huang S, Goldman RD: Alteration of nuclear lamin organization inhibits RNA polymerase II-dependent transcription. J Cell Biol 2002, 156:603-8.
58. Hyttel P, Viuff D, Avery B, Laurincik J, Greve T: Transcription and cell cycledependent development of intranuclear bodies and granules in two-cell bovine embryos. J Reprod Fertil 1996, 108:263-270.

59. Viuff D, Hyttel P, Avery B, Vajta G, Greve T, Callesen H, Thomsen PD: Ribosomal ribonucleic acid is transcribed at the 4-cell stage in in vitroproduced bovine embryos. Biol Reprod 1998, 59:626-631.

60. Memili E, First NL: Control of gene expression at the onset of bovine embryonic development. Biol Reprod 1999, 61:1198-1207.

61. Frei RE, Schultz GA, Church RB: Qualitative and quantitative changes in protein synthesis occur at the 8-16-cell stage of embryogenesis in the cow. J Reprod Fertil 1989, 86:637-641.

62. Memili E, Dominko T, First NL: Onset of transcription in bovine oocytes and preimplantation embryos. Mol Reprod Dev 1998, 51:36-41.

63. Canel N, Bevacqua R, Fernández-Martín R, Salamone DF: Activation with ionomycin followed by dehydroleucodine and cytochalasin B for the production of parthenogenetic and cloned bovine embryos. Cell Reprogram 2010, 12:491-9.

64. Bhak JS, Lee SL, Ock SA, Mohana Kumar B, Choe SY, Rho GJ: Developmental rate and ploidy of embryos produced by nuclear transfer with different activation treatments in cattle. Anim Reprod Sci 2006, 92:37-49.

65. Yoo JG, Choe SY, Rho GJ: Efficient production of cloned bovine embryos using cdc2 kinase inhibitor. Reprod Domest Anim 2003, 38:444-450.

66. Ikawa M, Kominami K, Yoshimura Y, Tanaka K, Nishimune Y, Okabe M: A rapid and non-invasive selection of transgenic embryos before implantation using green fluorescent protein (GFP). FEBS Lett 2005, 375:125-128.

67. Brackett B, Oliphant G: Capacitation of rabbit spermatozoa in vitro. Biol Reprod 1975, 12:260-274

68. Tervit $H$, Whittingham $D$, Rowson L: Successful culture in vitro of sheep and cattle ova. J Reprod Fertil 1972, 30:493-497.

69. Holm P, Booth PJ, Schmidt MH, Greve T, Callesen H: High bovine blastocyst development in a static in vitro production system using SOFaa medium supplemented with sodium citrate and myo-inositol with or without serum-proteins. Theriogenology 1999, 52:683-700.

doi:10.1186/1747-1028-7-23

Cite this article as: Canel et al:: Replication of somatic micronuclei in bovine enucleated oocytes. Cell Division 2012 7:23.

\section{Submit your next manuscript to BioMed Central and take full advantage of:}

- Convenient online submission

- Thorough peer review

- No space constraints or color figure charges

- Immediate publication on acceptance

- Inclusion in PubMed, CAS, Scopus and Google Scholar

- Research which is freely available for redistribution 